\title{
Frequency of Abnormal Thyroid Function Tests in Kuwaiti Arabs with Autoimmune Diseases
}

\author{
A.M. Al-Awadhia ${ }^{a}$ S. Olusib ${ }^{\text {b.A. Hasan }}{ }^{c} \quad$ A. Abdullah ${ }^{d}$ \\ Departments of a Medicine and ${ }^{\mathrm{b}}$ Pathology, Faculty of Medicine, Kuwait University, ${ }^{\mathrm{C}} \mathrm{Al}$-Amiri and \\ ${ }^{\mathrm{d}}$ Mubarak Al-Kabeer Hospitals, Ministry of Health, Kuwait
}

\section{Key Words}

Abnormal thyroid functions - Thyroid autoantibodies •

Autoimmune diseases

\begin{abstract}
Objectives: The purpose of this study was to examine the frequencies of abnormal thyroid function tests and serum thyroid autoantibodies in healthy Kuwaitis and those with autoimmune diseases. Subjects and Methods: Serum concentrations of sensitive thyrotropin, and free thyroxine were measured in 577 apparently healthy controls, 177 patients with rheumatoid arthritis (RA), 60 with systemic lupus erythematosus (SLE) and 25 with primary Sjogren's syndrome (pSS) using the immunochemiluminescent assay method on IMMULITE 1000. Serum microsomal and thyroglobulin autoantibodies were also measured by passive hemagglutination assay. For analysis of the thyroid function tests, the subjects were classified into five categories: normal, subclinical hypothyroidism, overt hypothyroidism, euthyroid sick syndrome and biochemical hyperthyroidism. Results: Subclinical hypothyroidism was seen in $1.7 \%$ of healthy controls, $10.2 \%$ of RA, $13.3 \%$ of SLE, and $16 \%$ of pSS patients. Among RA patients, the frequency of subclinical hypothyroidism in females (11.4\%) was significantly higher than among males (5.4\%; $p<0.01)$. In SLE and pSS patients, all those with subclinical hypothyroidism were females. Overt hypothyroidism was seen in $1.4 \%$ of controls, $10.2 \%$ of RA, $8.3 \%$ of SLE,
\end{abstract}

and $4 \%$ of pSS patients. Biochemical hyperthyroidism was seen in $0.2 \%$ of controls, $4.5 \%$ of RA, $5 \%$ of SLE and none of pSS patients. The euthyroid sick syndrome was seen in $0.4 \%$ of controls, $13.6 \%$ of RA, $16.7 \%$ of SLE and in none of pSS patients. Thyroid autoantibodies were present in 3.1\% of controls, $12.4 \%$ of RA, $18.3 \%$ of SLE, and $12 \%$ of pSS patients. Conclusion: Our data show that abnormal thyroid function tests and thyroid autoantibodies occur frequently in Kuwaitis with autoimmune diseases. Therefore, ordering these tests in these diseases is recommended.

Copyright $\odot 2007$ S. Karger AG, Base

\section{Introduction}

Autoimmune diseases such as rheumatoid arthritis (RA), systemic lupus erythematosus (SLE), primary Sjogren's syndrome (pSS) and Graves' disease are often seen among Kuwaitis [1] and they therefore constitute a health challenge to the community. What is perhaps more important is that thyroid autoimmune disorders, which may be life-threatening, are often associated with these autoimmune diseases as exemplified in RA, scleroderma, pSS, vasculitides and SLE [2-10]. However, the prevalence of these thyroid disorders differs from population to population [11-15] and the prevalence of thyroid autoantibodies in different populations is somewhat variable.

\section{KARGER}

Fax +41613061234

E-Mail karger@karger.ch

www.karger.com (c) 2007 S. Karger AG, Basel

$1011-7571 / 08 / 0171-0061 \$ 24.50 / 0$

Accessible online at:

www.karger.com/mpp
Dr. Adel M. Al-Awadhi

Department of Medicine, Faculty of Medicine, Kuwait University PO Box 24923

13110 Al-Safat (Kuwait)

Tel. +965 531 9596, Fax +965 533 3955, E-Mail aalawadhi@hsc.edu.kw 
Table 1. Demographic data of the different groups investigated

\begin{tabular}{lllll}
\hline Characteristics & Controls & RA & SLE & pSS \\
\hline Total subjects & 577 & 177 & 60 & 25 \\
Males & 200 & 37 & 1 & 2 \\
Females & 377 & 140 & 59 & 23 \\
Female:male ratio & $1.9: 1$ & $4: 1$ & $59: 1$ & $11.5: 1$ \\
Age, years & $36.8 \pm 10.3$ & $38.3 \pm 12.8$ & $42.3 \pm 10.8$ & $45.8 \pm 15.2$ \\
\hline
\end{tabular}

Values for age are expressed as mean $\pm \mathrm{SD}$.
There have been no detailed reports in the literature on the frequency of abnormal thyroid function tests and the presence of thyroid autoantibodies in healthy $\mathrm{Ku}$ waitis or in those with autoimmune diseases other than our previous short report limited to the prevalence of hypothyroidism in patients with RA [16], but there are detailed reports on other Arabs $[17,18]$. Therefore, the present study was designed to investigate the frequency of abnormal thyroid function tests in healthy Kuwaiti Arabs and in those with RA, SLE, and pSS.

\section{Subjects and Methods}

\section{Patients}

One hundred and seventy-seven (37 males, 140 females) consecutive ambulatory patients with RA, 60 (1 male, 59 females) with SLE and 25 ( 2 males, 23 females) with pSS from Al-Amiri and Mubarak Al-Kabeer Hospitals in Kuwait fulfilling the American College of Rheumatology criteria for RA [19], SLE [20] and pSS [21] were recruited into the study. The RA and SLE patients were not in a flare of their disease based on the DAS-28 score (less than 2.4) for RA and the SLE Disease Activity Index (less than 3) for the SLE group.

\section{Controls}

Five hundred and seventy-seven apparently healthy controls (200 males and 377 females) aged 18 years and older were recruited from a house to house survey of the Kuwaiti households carried out according to our previous publication [22]. The mean age \pm standard deviation of this group was $36.8 \pm 10.3$ years. None of the controls had any prior history or clinical diagnosis of rheumatic disease, or acute systemic disease and none was on any medications known to affect thyroid function tests. Informed consent was obtained from each subject and the study was approved by the Ethical Committee, Faculty of Medicine, Kuwait University, Kuwait.

\section{Thyroid Function Tests}

Blood $(10 \mathrm{ml})$ samples were collected from the patients and controls, serum separated and kept frozen at $-80^{\circ} \mathrm{C}$ until ready for assay.
Free thyroxine $\left(\mathrm{FT}_{4}\right)$ and sensitive thyroid stimulating hormone (TSH) were measured in the serum samples by immunochemiluminescent assay on the IMMULITE 1000 (Diagnostic Products Corporation, Los Angeles, Calif., USA) and compared with the normal reference ranges in our laboratory for $\mathrm{FT}_{4}: 9.2-$ $23.8 \mathrm{pM}$, and TSH: $0.23-4.0 \mathrm{mU} / \mathrm{l}$. Passive hemagglutination assays, Thymune-M and Thymune-T (Remel Europe Ltd, Kent, UK) were used to measure thyroid microsomal antibody and thyroglobulin autoantibody, respectively.

For analysis, the subjects were classified into the following five groups: (a) normal: normal $\mathrm{FT}_{4}$ and normal TSH levels; (b) subclinical hypothyroidism: normal $\mathrm{FT}_{4}$, but high TSH ( $\left.>4.0 \mathrm{mU} / \mathrm{l}\right)$; (c) overt hypothyroidism: low $\mathrm{FT}_{4}(<9.2 \mathrm{pmol} / \mathrm{l})$, but high TSH; (d) euthyroid sick syndrome: normal/low $\mathrm{FT}_{4}$ but normal TSH; and (e) biochemical hyperthyroidism: normal or high $\mathrm{FT}_{4}(>23.8$ $\mathrm{pM})$ and low TSH $(<0.23 \mathrm{mU} / \mathrm{l})$.

\section{Statistical Analysis}

Group data were analyzed for statistical significance using the Scheffé test in the computerized ANOVA program for multiple comparisons. The $\chi^{2}$ and Fischer exact tests were used for comparison of percentages. A p value of $<0.05$ was accepted as significant.

\section{Results}

\section{Demographic Data}

The demographics of the study group are given in table 1. In general, the females outnumbered the males with as low a ratio of 1.9:1 in control to 59:1 in SLE patients. The mean ages were from $36.8 \pm 10.3$ in controls to $45.8 \pm 15.2$ in pSS patients. Patients with pSS are rare in Kuwait, hence the small number studied.

The frequency of abnormal thyroid function tests in the different groups are listed in table 2 . Subclinical hypothyroidism was seen in $10(1.7 \%)$ controls, 18 (10.2\%) RA, 8 (13.3\%) SLE and 4 (16\%) pSS patients. The frequency of subclinical hypothyroidism in pSS, SLE, and RA were significantly higher $(\mathrm{p}<0.01)$ than in the control group, with that in pSS being the highest. The frequency of subclinical hypothyroidism in females was significant- 
Table 2. Frequency of thyroid function tests in the different groups investigated

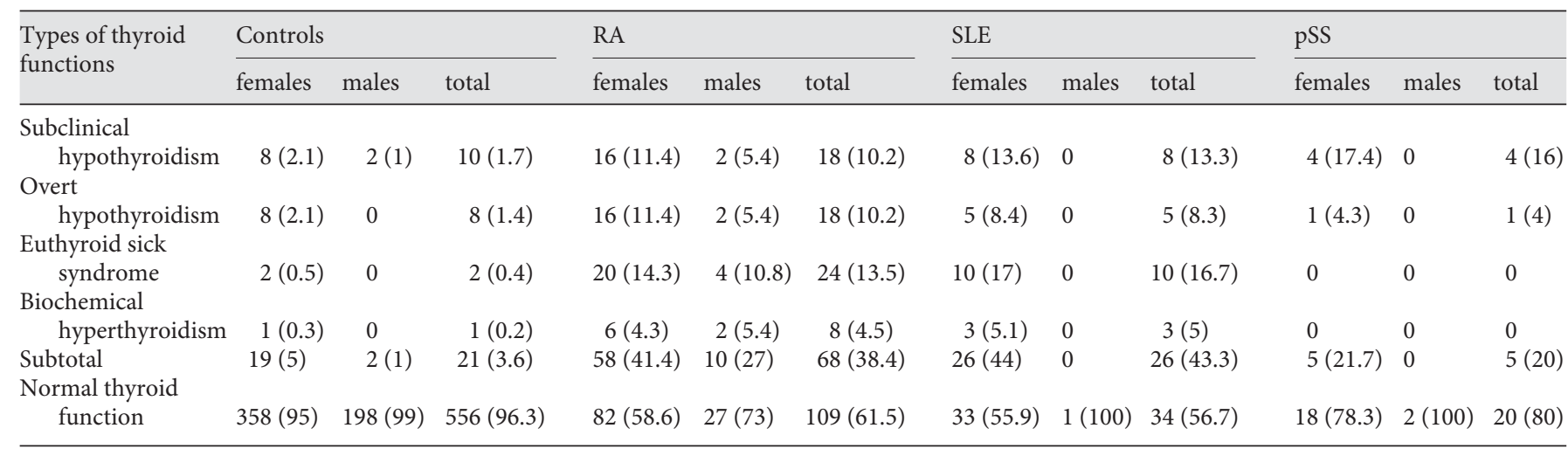

Figures in parentheses are percentages.

Table 3. Frequency of thyroid autoantibodies in the different groups investigated

\begin{tabular}{|c|c|c|c|c|c|c|c|c|c|c|c|c|}
\hline Thyroid autoantibody & \multicolumn{3}{|l|}{ Controls } & \multicolumn{3}{|l|}{ RA } & \multicolumn{3}{|l|}{ SLE } & \multicolumn{3}{|l|}{ pSS } \\
\hline $\begin{array}{l}\text { Microsomal antibody } \\
\quad(\text { normal < } 75 \mathrm{IU} / \mathrm{ml})\end{array}$ & \multicolumn{12}{|c|}{ Microsomal antibody } \\
\hline Thyroglobulin antibody & & & & & & & & & & & & \\
\hline (normal <115 IU/ml) & $3(0.8)$ & $1(0.5)$ & $4(0.7)$ & $4(2.9)$ & $2(5.4)$ & $6(3.4)$ & $4(6.8)$ & 0 & $4(6.7)$ & $2(8.7)$ & 0 & $2(8.0)$ \\
\hline Both antibodies & $2(0.5)$ & 0 & $2(0.3)$ & $3(2.1)$ & $1(2.7)$ & $4(2.3)$ & $3(5.0)$ & 0 & $3(5.0)$ & 0 & 0 & 0 \\
\hline
\end{tabular}

Figures in parentheses are percentages.

ly higher than in male control subjects and RA patients $(\mathrm{p}<0.01)$. Its frequency among females was $13.6 \%$ in SLE and $17.4 \%$ in pSS. Also the frequencies of subclinical hypothyroidism in females with RA, SLE and pSS were significantly higher than in female controls $(\mathrm{p}<0.01)$. Overt hypothyroidism was more frequent among RA patients $(18 ; 10.2 \%)$ than healthy controls $(8 ; 1.4 \%)$. It was seen in $5(8.3 \%)$ in SLE and 1 (4\%) in pSS. The frequency of this condition was higher among females with RA than among females with SLE, pSS, or healthy females $(\mathrm{p}<0.01)$.

Biochemical hyperthyroidism was seen in $8(4.5 \%)$ RA, 3 (5\%) SLE and $1(0.2 \%)$ normal patients. Biochemical hyperthyroidism was not seen in any patient with pSS.

In total, the frequency of abnormal thyroid function tests was seen in 21 (3.6\%) healthy controls, 68 (38.4\%) RA, 26 (43.3\%) SLE, and 5 (20\%) pSS patients (table 2). The difference between controls and RA, SLE or pSS patients was statistically significant $(p<0.01)$. Moreover, females had significantly higher frequency of abnormal thyroid function tests than males in RA $(58,41.4 \%$ vs. 10 , $27 \%), \operatorname{SLE}(26,44.3$ vs. $0 \%)$ and pSS ( $5,21.7$ vs. $0 \%)$ groups (table 2). In general, abnormal thyroid function tests were seen more commonly in patients with autoimmune diseases than in the healthy control subjects. Their frequencies in females are about twice the male frequency.

The frequency of thyroid autoantibodies is listed in table 3. Microsomal autoantibodies were found in 14 (2.4\%) of the controls. The microsomal autoantibodies were less in controls than in patients with RA, SLE or pSS. Both microsomal and thyroglobulin autoantibodies were seen in control: 2; RA: 4 and SLE: 3 patients, while microsomal autoantibodies alone were seen in $12(2.1 \%)$ controls, 12 (6.7\%) RA, 4 (6.7\%) SLE and 1 (4\%) pSS. Thyroglobulin autoantibodies alone were seen in $4(0.7 \%)$ controls, 6 (3.4\%) RA, 4 (6.7\%) SLE and 2 (8\%) pSS patients. In general, less microsomal or thyroglobulin autoantibodies were seen in controls than in RA, SLE, or pSS patients. Females had more of these antibodies than males. 


\section{Discussion}

The frequencies of thyroid dysfunctions in our study are considerably lower than those reported for other populations [11-15], most probably due to the small sample size (577 out of a population of 1 million). Hence, definite inference may not be drawn from this study until a larger sample size has been investigated to confirm the present observations.

In our study, the frequency of subclinical hypothyroidism was higher in patients with autoimmune diseases than in the healthy individuals. All patients were females in SLE and pSS groups and comprised $88.9 \%$ in the RA group. Our data are similar to those reported for other populations [5-10]. Previous studies have shown that a number of patients with subclinical hypothyroidism will eventually develop clinical hypothyroidism [12]. The risk factors for this progression are advanced age, female gender and presence of thyroid antibodies [11]. In this study, the mean age of our patients with subclinical hypothyroidism was below 45 in RA ( $40.5 \pm 8.6$ years) or SLE ( $43.5 \pm 10$ years) patients but above 45 years in pSS (50.6 \pm 12.6 years) patients, suggesting that Kuwaiti patients above the age of 45 years with pSS need to be monitored carefully for clinical hypothyroidism.

The mean ages for the overt hypothyroid group in RA ( $49 \pm 5.2$ years), SLE $(50.6 \pm 6.3$ years $)$ or pSS (53.5 \pm 10.6 years) patients were higher than those of the subclinical hypothyroid group. These results support a 'disease pyramid' in autoimmune thyroiditis in which patients progress from mild thyroiditis to clinical hypothyroidism over time [23, 24].

Punzi et al. [25] found a higher frequency of thyroid disorders in pSS (13.4\%) than in RA (3.1\%) patients from Italy. However, thyroid dysfunction was lower in our patients with pSS compared with those with RA or SLE. Perez et al. [26] reported higher frequency of thyroid dys- function in Mexican patients with pSS (45\%) compared with our data. These variances may be attributed to different environmental factors of the different populations. Genetic difference could also be a plausible explanation.

Some population studies have shown variable prevalence of thyroid autoantibodies in the general population especially among females [27-30]. However, the frequency of thyroid antibodies in Kuwaiti healthy individuals in our study was low compared with the $12.4 \%$ found by O'Leary et al. [27] among Australians and 5.7\% among Omanis reported by Al-Jabri et al. [17]. The reason for these discrepancies can not be explained clearly, but it may be due to ethnic differences, and unknown genetic or environmental factors. Our study confirmed that the frequency of autoantibodies is much higher in females than in males both in the control group and in patients with RA or SLE or PSS, suggesting that the development of hypothyroidism is enhanced particularly among females by the presence of thyroid autoantibodies.

The pathogenesis of thyroid disorders in autoimmune disease may have a common pathway. Since autoimmune disease like RA or SLE is a systemic disorder that can affect any organ in the body, it could be speculated that the abnormal thyroid function tests seen in autoimmune diseases are due to the thyroid activity of one of the autoantibodies produced in these diseases [31, 32].

\section{Conclusion}

Our study showed that abnormal thyroid function tests, particularly hypothyroidism, occur frequently in Kuwaiti patients with systemic autoimmune diseases. Those who are at high risk (female gender and positive thyroid autoantibody) should have thyroid function test follow-up and should be given appropriate treatment whenever clinical hypothyroidism develops.

\section{References}

-1 Al-Awadhi AM, Olusi SO, Al-Saeid K, Moussa $\mathrm{M}$, Shehab D, Al-Zaid N, Al-Herz A, AlJarallah K: Incidence of musculoskeletal pain in adult Kuwaitis using the validated Arabic Version of WHO-ILAR COPCORD Core. Questionnaire. Ann Saudi Med 2005; 25:459-462.

-2 Becker KL, Ferguson RH, McConahey WM: The connective tissue diseases and symptoms associated with Hashimoto's thyroiditis. New Engl J Med 1963;268:277-280.
>3 Karsh J, Pavlidis N, Weintraub BD, Moutsopoulus HM: Thyroid disease in Sjogren's syndrome. Arthritis Rheum 1980;23:13261329.

4 Gordon MB, Klein I, Dekker A, Rodnan GP, Medsger TA: Thyroid disease in progressive systemic sclerosis: increased frequency of glandular fibrosis and hypothyroidism. Ann Intern Med 1981;95:431-435.

$\checkmark 5$ Delamere JP, Scott DL, Felix-Davies DD: Thyroid dysfunction and rheumatic diseases. J R Soc Med 1982;75:102-106.
6 Thomas DJB, Young A, Gorsuch AN, Bottazzo GF: Evidence for an association between rheumatoid arthritis and autoimmune endocrine disease. Ann Rheum Dis 1983;42:297-300.

$>7$ Weetman AP, Walport MJ: The association of autoimmune thyroiditis with systemic lupus erythematosus. Br J Rheumatol 1987;26: 359-361.

$>8$ Goh KL, Wang F: Thyroid disorders in systemic lupus erythematosus. Ann Rheum Dis 1986;45:579-583. 
9 Miller FW, Moore GF, Weitraub BD, Steinberg AD: Prevalence of thyroid disease and abnormal thyroid function test results in patients with systemic lupus erythematosus. Arthritis Rheum 1987;30:1124-1131.

10 Lesser RS, Metzger DS, Dettoratius RJ: Hypothyroidism in an outpatient SLE population. Arthritis Rheum 1988;3:R4.

-11 Tunbridge WMG, Evered DC, Hall R, Appleton D, Brewis M, Clark F, Evans JG, Young E, Bird T, Smith PA: The spectrum of thyroid disease in a community: the Whickham Survey. Clin Endocrinol 1977;7:481-493.

$\checkmark 12$ Vanderpump MPJ, Tunbridge WMG, French JM, Appleton D, Bates D, Clark F, Grimley Evans J, Hasan DM, Rodgers H, Tunbridge F: The incidence of thyroid disorders in the community: a twenty year follow-up of the Whickham Survey. Clin Endocrinol 1995. 43:55-68.

13 Peterson K, Lindstedt G, Lundberg PA, Bengtsson C, Lapidus L, Nystrom E: Thyroid disease in middle-aged and elderly Swedish women: thyroid related hormones, thyroid dysfunction and goitre in relation to age and smoking. J Intern Med 1991;229:407-413.

- 14 Parle JV, Franklyn JA, Cross KW, Jones SC, Sheppard MC: Prevalence and follow-up of abnormal thyrotropin levels (TSH) concentrations in the elderly in the United Kingdom. Clin Endocrinol (OXF) 1991;34:7783.

-15 Tomimori E, Pedrinola F, Cavalieri H, Knobel M, Medeiros-Neto G: Prevalence of incidental thyroid disease in a relatively low iodine intake area. Thyroid 1995;5:273-276.

- 16 Al-Awadhi AM, Olusi SO, Al-Zaid NS, Prabha K, Al-Ali N, Al-Jarallah KH, George S: Prevalence of hypothyroidism among Arabs with rheumatoid arthritis. Rheumatol 1999;38:472-473.

17 Al-Jabri AA, Al-Belushi MS, Nsanze H: Frequency and levels of autoantibodies in healthy adult Omanis. Ann Saudi Med 2003; 23:372-375.
18 El-Sherif WT, El-Gendi SS, Ashmawy MM, Ahmed HM, Salma MM: Thyroid disorders and autoantibodies in systemic lupus erythematosus and rheumatoid arthritis patients. Egypt J Immunol 2004;11:81-90.

19 Arnett FC, Edworthy SM, Bloch DA, McShane DJ, Fries JF, Cooper NS, Healey LA, Kaplan SR, Liang MH, Luthra HS: The American Rheumatism Association 1987 revised criteria for the classification of RA. Arthritis Rheum 1988;31:315-324.

20 Tan EM, Cohen AS, Fries JF, Masi AT, McShane DJ, Rothfield NF, Schaller JG, Talal N, Winchester RJ: The 1982 revised criteria for the classification of systemic lupus erythematosus. Arthritis Rheum 1982;25:1271 1277.

21 Vitali C, Bombardieri S, Josson R, Moutsopoulos HM, Alexander EL, Carsons SE, Daniels TE, Fox PC, Kassan SS, Pillemer SR, Talal N, Weisman MH; European Study Group on Classification Criteria for Sjogren's Syndrome: Classification criteria for Sjogren's syndrome: a revised version of the European criteria proposed by the American - European Consensus Group. Ann Rheum Dis 2002;61:554-558.

22 Al-Awadhi AM, Olusi SO, Moussa M, Shehab D, Al-Zaid N, Al-Herz A, Al-Jarallah K: Musculoskeletal pain, disability and healthseeking behaviour in adult Kuwaitis using the validated Arabic version of the WHOILAR COPCORD Core Questionnaire. Clin Exp Rheumatol 2004;22:177-183.

-23 Nordyke RA, Gilbert FI Jr, Miyamoto LA, Fleury KA: The superiority of antimicrosomal over antithyroglobulin antibodies for detecting Hashimotos's thyroiditis. Arch Intern Med 1993;153:862-865.

24 Dayan CM: The natural history of autoimmune thyroiditis: how normal is autoimmunity? Proc R Coll Physicians Edinb 1996;26: 419-433.
25 Punzi L, Ostuni PA, Betterle C, De Sandre P, Botsios C, Gambari PF: Thyroid gland disorders in primary Sjogren's syndrome. Rev Rhum Engl Ed 1996;63:809-814.

26 Perez B, Kraus A, Lopez G, Cifuentes M, Alarcon-Segovia D: Autoimmune thyroid disease in primary Sjogren's syndrome. Am J Med 1995;99:480-484.

27 O'Leary PC, Feddema PH, Michelangeli VP, Leedman PJ, Leedman PJ, Chew GT, Knuiman M, Kaye J, Walsh JP: Investigations of thyroid hormones and antibodies based on a community health survey: the Busselton thyroid study. Clin Endocrinol 2006;64:97104 .

28 Hoogendoorn EH, Hermus AR, de Vegt F, Ross HA, Verbeek AL, Kiemeney LA, Swinkels DW, Sweep FC, den Heijer M: Thyroid function and prevalence of anti-thyroperoxidase antibodies in a population with borderline sufficient iodine intake influences of age and sex. Clin Chem 2006;52:104-111.

29 Quinn FA, Gridasov GN, Vdovenko SA, Krasnova NA, Vodopianova NV, Epiphanova MA, Schulten M: Prevalence of abnormal thyroid peroxidase antibody-positive results in a population of pregnant women in the $\mathrm{Sa}$ mara region of the Russian Federation. Clin Chem Lab Med 2005;43:1223-1226.

30 Bulow Pederson I, Laurberg P, Knudsen N, Jorgensen T, Perrild H, Ovesen L, Rasnussen LB: A population study of the association between thyroid autoantibodies in serum and abnormalities in thyroid function and structure. Clin Endocrinol (Oxf) 2005;62:713720 .

31 Scofield RH: Autoantibodies as predictors of disease. Lancet 2004;363:1544-1546.

-32 Szyper-Kravitz M, Marai I, Shoenfeld Y: Coexistence of thyroid autoimmunity with other autoimmune diseases: friend or foe? Additional aspects on the mosaic of autoimmunity. Autoimmunity 2005;38:247-255. 